\title{
ЗА КОНИ
}

Др Александар Јовичин адвокат у Новом Саду

\section{НЕКА ПИТАҢА У ВЕЗИ ЗАКОНА \\ О ДЕВИЗНОМ ПОСЛОВАҢУ*}

\section{Yвod}

Савезна скупштина, на седници Већа Република од 28. фебруара 1995. године и на седници Већ̆а грађана од 1. марта 1995. годнне

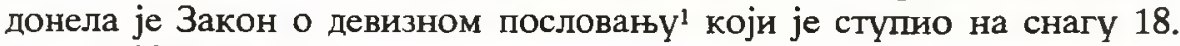
марта 1995. годнне.

Законом су регулисана бројна питања плаћања и наплаћ̆ивања у пословима с иностранством као и друга питања везана за девизно пословање.

Намера нам је да размотримо и прокоментаришемо само нека питања из овог значајног Закона, пре свега, имајући у виду потребе правне праксе, са којом ће се сусретати најшири круг привредних субјеката и граБана. У том циљу обухватићемо основне одредбе Закона, платни промет са иностранством, девизно пословање банака, располагање девизама од стране физичких лица, изношење и уношење динара и девиза, као и кривична дела и привредне преступе одреБене Законом.

\section{Основне одредбе и начела}

Законом је дата дефиниција којом се појам девиза одреБује као потраживање у иностранству које гласи на страну валуту. Истим

* Рал примъен: 20. IV 1995.

1 Закон о девизном пословању, Сл. лист СРЈ, бр. 12 од 10. марта 1995. 
појмом обухваћен је и ефективни страни новац, осим кованог златног новца. ${ }^{2}$

Према одредбама Закона забрањена је свака куповина и продаја девиза ван јединственог девизног тржишта, јер се девизе купују и продају на јединственом девизном тржишту, осим ако законом није друкчнје одреБено.

Поред тога, забрањено је плаћање и наплаһ̆ивање у девизама или злату измеБу домаћих лица, измеbу страних лица и измеbу домаћих и страних лица у Јутославији. Можда још значајније је то, да је забрањено закључнвање послова којима се обезбеbује да he ce вредност уговорене об̆авезе у новим динарима израчунавати на основу цене злата или на основу курса новог динара у односу на стране валуте, с обзиром да знамо колико су бројне такве клаузуле у уговорнма.

Одредбама закона, у односу на девизно пословање, изједначени су свн привредно-правни субјекти иако су у закону употребљена два термина као што су правно лице и предузетник, што се могло решити на једноставнији начнн.

У погледу овлашћења банака, у смислу закона о девизном пословању, направљена је разлика измеbу банке овлашћене за послове с иностранством и банке овлашћене за девизне послове у земљи.

Према одредбн закона, ${ }^{3}$ овлашћена банка јесте банка која има овлашћење да врши платни промет с иностранством и креднтне послове с иностранством. МеБутим, под истим појмом овлашћена банка је и банка која има овлашиење да обавља девизно-валутне послове у Југославији.

Из наведене одредбе, мада недовољно прецнзне, произилази да банка може имати само једно или друго овлашћење, а н оба тј. може бити овлашћ̆ена да врши и платни промет и кредитне послове послове са иностранством и девизно-валутне послове у Јутославији. МеБутим банка може имати само овлашћење да обавља девизно-валутне послове у Југославији.

Може се поставити питање да ли је банци која има овлашиење да врши платни промет и кредитне послове с иностранством потребно и посебно овлашйење за обавьање девизно-валутних послова у земљи, или је то садржано у једном овлашћењу. Мишљења смо да уколико је банка овлашћена да врши платни промет и кредитне послове с иностранством то подразумева н овлашћење да обавља девизно-валутне послове у Југославији, јер без тога је немогуће вршење платног промета и кредитних послова с иностранством, мада наведена законска одредба у том погледу није довољно прецизна.

На крају, треба рећи, да девизе правно лице и предузетник држе на свом девизном рачуну код овлашћене банке или га продају овлашћеној банци, а на те девизе банке не плаһају камату.

2 Чл. 2. ст. 1. Закона.

3 Чл. 6. Захона. 
Таква законска одредба према којој овлашћене банке само изузетно плаћају камату, кад девизе потичу из инвестиционих радова у иностранству, у најмању руку је чудна и дестимулативна за привредне субјекте, поготово када се зна да је недостатак девиза стално присутан у нашој привреди.

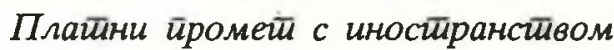

Платни промет с иностранством врши се у девизама и у новим динарима, у складу са закљученим меБународним уговором, на начин који прописује Народна банка Југославије.

Извезена роба и извршене услуге, као и друга потраживања наплаћују се у уговореном року који не може бити дужи од 60 дана, изузев код наплате у оквиру привредннх делатности у слободним и царинским зонама и услуга извршених у ваздушном, железничком, друмском, поморском, речном и ПТТ саобраћају, где се наплата врши у уговореном року, односно у року прописаном меБународним уговором.

Када се извршени извоз наплаћује у динарима исплата нових динара за извршени извоз робе и услуга врши се у року од два дана од дана када је банка обавештена о наплати, ако уговором није друкчије одреБено, и то по куповном курсу који важи на дан нсплате. ${ }^{4}$

Плаћање по текућим трансакцијама с иностранством, као и плаћање друтих обавеза врши се слободно на основу налога правног или физичког лица који су дужни да, ако не располажу девизама на свом девизном рачуну, у уговореном року уплате нове динаре по продајном курсу. Правно лице и предузетник могу плаһати само увезену робу и извршене услуге а само изузетно плаћање увоза робе може се вршити унапред, у случајевима које прописује Народна банка Југославије.

Правно лище и предузетник дужни су да робу, односно услугу плаћену унапред, увезу у року 60 дана од дана извшења налога за плаћање, изузев у оквиру привредних делатности у царинским и слободним зонама где се плаћање врши у року предвиБеном уговором.

Треба напоменути да предузеће које врши услуте у меБународном робном и путничком превозу и ПТТ саобраћају и организацији за осигурање имовине и лица могу уговарати плаћање и наплаћивање услуга преко контокорентног рачуна који се успоставља са страним лищима, за који су законом прописана посебна правила.

Законом су одреБена посебна правила за девизно пословање неких привредно-правних субјеката као што су организације за осигурање имовине и лица, организације које изводе инвестиционе

4 Чл. 26. ст. 1. и 2. Закона. 
радове у иностранству и оне које извозе или увозе робу или услуге по основу уговора о дугорочној производној кооперацији.

\section{Девизно йословање банака}

Услове за девизно пословање банака прописује Народна банка Јутославије.

Народна банка Југославије даје и овлашћење банкама за вршење послова платног промета с иностранством, кредитних послова с нностранством и девизно-валутних послова у Јутославији и води регистар тих банака. 5

Овлашћена банка за послове с иностранством може држати девизе на рачунима код страних банака, чије најмање и највеће износе девиза које та банка може држати на рачунима у иностранству прописује Народна банка Југославије.

Овлашћена банка може вршити конверзију девиза на девизном рачуну за плаһ̆ње иностранству, с тим да Народна банка Југославије може привремено ограничити конверзију девиза на девизном рачуну правних лица у новим динарима. Банка овлашћена за послове с иностранством може на страним девизним тржиштима куповати и продавати девизе само под условнма које пропише Народна банка Југославије.

Мењачки послови, према одредбама закона, су куповина ефективног страног новца, путничких и банкарских чекова, кредитних писама, бонова за путарнну страних регистрација и бензннских бонова од домаһ̆их и страних физнчких лица. Те послове може вршити овлашћена банка, односно друго правно лице и предузетник с којим банка закључи уговор, с тим, што треба напоменутн, да се сви мењачки послови врше за рачун Народне банке Југославије, под условима које она пропише. 6

Посебан режим имају девизе остварене продајом или давањем у закуп станова, пословног простора и друге имовине Јүгославије, девизе остварене наплатом такса и по друтим основима утврьеним савезним прописима. Према одредби закона те девизе продају се Народној банци Југославије. ${ }^{7}$

\section{Расйолайане девизама од сииране физичких лица}

Домаћа и страна физичка лица могу држати девизе на девизном рачуну или девнзној штедној књижнци код овлашћене банке. Исто тако, верске заједнице, фондови и фондације, легати, задужбине,

5 Чл. 45. ст. 1. Закона.

6 Чл. 52. ст. 1. н 2. Закона.

7 Чл. 53. Закона. 
хуманитарне организације и удружења грађана могу девизе прибављене по основу поклона и хуманитарне помоћи држати на девизном рачуну или девизној штедној књижици.

За девизе положене на девизне рачуне и девизне штедне књижице гарантује банка својом укупном имовином. Овлашћена банка дужна је да по основу положених девиза изврши обрачун и исплати камату у девизама или на захтев физичког лица, у новим динарима.

Са свог девизног рачуна домаһа или страна физичка лица могу подизати ефективан страни новац или, своја потраживања по основу држања девиза на девизном рачуну или на девизној штедној књижици продати домаћем правном или физичком личу преко овлашћене банке.

Посебан режим имају девизе које су физичка лица положила на девизни рачун или девизну штедну књижицу код овлашћене банке пре ступања на снагу овог закона.

Према изричитој законској одредби ${ }^{8}$ за те девизе јемчи држава у складу са овим и другим савезним законом. Мебутим, обавезе по основу овог јемства настају тек даном доношења решења о отварању стечајног поступка над банком. На ове девизе овлашћене банке плаћају камату домаћим физичким лищима у динарима или на њихов захтев у девизама, док код страних физичких лица важи обрнут принцип, што значи у девизама а на њихов захтев камата се исплаћује у динарима.

Овлашћене банке дужне су да обезбеде тајност података о девизним рачунима и девизним штедним књижицама домаћих и страних физичких лица, а обавештења о девизним рачунима и девизним штедним књижицама домаћих и страних физичких лица, могу се, према изричитој законској одредби, дати само на писмени захтев суда. ${ }^{9}$

На крају треба додати да домаћа физичка лица не могу имати рачуне у иностранству, не могу куповати стране хартије од вредности и не могу се задуживати у иностранству.

\section{Изнощење и уношење динара и девиза}

Нови динари се могу, у путничком промету с иностранством, износити из Југославије само у износима и апоенима које пропише Народна банка Југославије. Народна банка Југославије прописује и услове за изношење нових динара и хартија од вредности које гласе на нови динар, ефективног страног новца и хартија од вредности к้оје гласе на страну валуту, путем поштанеких и других пошиљака, и уношење нових динара и хартија од вредности које гласе на нове

\footnotetext{
8 Чл. 135. ст. 1. н 2. Закона.

9 Чл. 66. ст. 2. Закона.
} 
динаре, путем поштанских и других пошиљака, врши се под условима које пропише Народна банка Југославије.

Уношење девиза у Југославију је слободно. 10

Нови динари којима у Југославији располажу страна физичка лица и југословенски грађани на привременом раду у иностранству, а који потичу од девиза продатих овлашћеној банци, уживају посебан режим. Такви динари могу се износити из Југославије у прописаним апоенима и износима или употребити за куповину девиза ради трансфера у иностранство.

Југословенски граБани за време привременог рада у иностранству и за време рада у дипломатским и конзуларним представништвима Југославије и исељеници који су се вратили у Југославију могу имати рачуне у иностранству само док се не врате у земљу, јер се одредба Закона ${ }^{11}$ према којој домаћа физичка лица не могу имати рачуне у иностранству односи и на њих.

Југословенски грађани на привременом раду у иностранству и на раду у дипломатским и конзуларним представништвима Југославије који су се вратили у земљу дужни су да девизе којима располажу унесу у року од 30 дана од дана повратка. Ако то не учине чине прекршај који се кажњава новчаном казном од 300 до 1.500 динара.

Југословенски граБани за време привременог рада у иностранству и по дефинитивном повратку могу стране хартије од вредности свих врста наплаћивати преко банака овлашћених за послове с иностранством. Исто се односи и на домаћа физичка лица која по основу наслеђа и поклона остваре право на стране хартије од вредности, купоне страних хартија од вредности и стране уложне књижище.

Све наведене хартије од вредности могу се продати банци овлашћеној за послове с иностранством у девизама, или на захтев имаоца тих хартија у новим динарима.

На крају, треба додати, да чекови вучени на страна лица у Југославији не могу се препродавати нити индосирати у Југославији а чекови на нове динаре вучени у Јүгославији не могу се хонорисати ако се на њима налази индосамент страног лица, јер то представља прекршаје за које је предвиђена новчана казна утврьена законом.

\section{Кривична дела и ӣривредни ӣрестйуӣи}

Законом је одређено више кривичних дела за која је предвиБена казна затвора.

Као прво, инкриминисано је плаћање и наплаћивање у девизама или злату на територији Југославије на начин противан одредбама закона. За ово кривично дело запрећена је казна затвора од шест

10 Чл. 69. ст. 1. Закона.

11 Чл. 113. Захона. 
месеци до пет година. Изричнто је законом прописано кажњавање и за покушај извршења овог кривичног дела.

МеБутим, треба напоменути, да је иста радња „плаһање и наплаћивање у девизама или злату” одреБена и као привредни преступ, и да је погрешно уподобљена са закључивањем послова којима се обезбеьује да ће се уговорна обавеза изражена у новим динарима израчунавати на основу цене злата или курса новог динара у односу на стране валуте. Поред тога није јасна формулацнја према којој се у оба случаја наводи „плаһање и наплаћ̆ивање” што значи кумулациjу обе радње.

Све ово указује да hе у практичној примени наведених одредби ${ }^{12}$ Закона бити проблема.

Законом је одреБено да ко противно одредби тог Закона купује или продаје девизе у износу већем од 1.000 САД долара или организује мрежу препродаваца или посредника казниће се затвором од једне до пет година. Ово је дело са најтежом запрећеном казном, у овом Закону, а и за њега је изричито прописано кажњавање за покушај.

Ко не примењује јединствен курс новог динара на финансијске и друге економске трансакције, или га не примењује при куповнни или продаји девиза чини кривично дело са запрећеном затворском казном од три месеца до три године. Иста радња са краћ̆ом формулацијом „ако не примењује јединствен курс динара" предвиБена је као привредни преступ. Код овог кривичног дела законом је пропнсано да he се девизе које су предмет овог кривичног дела одузети.

Законом су одреБена још два кривична дела код којих извршилац може бити само одговорно лице у предузећу или другом правном липу или предузетник.

Према одредби Закона ${ }^{13}$ такво лице које у складу с одредбама тог Закона не држи девизе на девизном рачуну код овлашћене банке, односно не прода девизе, казниће се за то дело затвором од три месеца до три године а девизе које су предмет дела одузеће се.

Друго кривично дело чини одговорно лице у предузећу или другом правном лицу, односно предузетник који спречн орган надлежан за вршење девизне контроле да изврши увид у пословне књиге и другу документацију, за шта је запрећена казна затвора до три године.

Законом је одреБен велики број привредних преступа који су сврстани у две законске одредбе са запрећеним новчаним казнама од 15.000 до 150.000 динара, а за одговорна лица од 1000 до 10.000 нових динара, све у зависности о ком привредном преступу се радн.

Поред новчане казне за привредне преступе одреБене овим Законом, може се изрећи и заштитна мера забране правном лицу да

12 Чл. 114. ст. 1. и 2. и чл. 119. ст. 1. тачкка 2. Закона.

13 Чл. 117. ст. 1. и 2. Закона. 
се бави делатношћу чијим је обављањем учињен привредни преступ у трајању од једне до десет годнна.

За привредне преступе поред новчане казне изриче се и заштитна мера одузимања предмета који су били употребљени или су били намењени за извршење привредног преступа или који су настали извршењем привредног преступа.

Закон о девизном пословању свакако доприноси бољем правном регулисању ове области која је пре његовог доношења била уреБена ранијим законом донетим 1975. године оптерећеним многобројним изменама и допунама. У том погледу, доношењем овог Закона биһе свакако створени бољи услови за увођење више реда и дисциплине у овој области, уз напомену да је за његово извршавање потребно усклабивање и доношење великог броја прописа које треба да донесу Савезна влада и Народна банка Југославије.

МеБутим, мишљења смо да баш такав начин правног нормирања који је остварен у овом Закону требало је радикалније мењати у правиу либералнијег односа државе према привредно-правним субјектима. То је, по нашем мишљењу, неогходно уколико се жели да се створи амбијент који треба да подстиче привредне и све друге субјекте за савременије и профитабилније пословање и повезивање са одговарајућим субјектима у иностранству, без обзира што знамо да је у ситуацији под санкшијама, које сада имамо, то тешко остварити.

У Закону има превише одредаба које упућују на додатно регулисање прописима нижег ранга што неминовно у његовој практичној примени може довести до проблема а и угрозити сам конщепт закона. Такво правно регулисање односа увек у пракси ствара администрирање уместо да се подстиче аутономија привредних субјеката и предузетника.

Посебно треба истаћи да је законом одреБен превелик број радњи које су санкиионисане ригорозним запрећеним казнама, било да се ради о кривичним делима, привредним преступима или прекршајима. То указује да се законодавац није ослободно старих схватања да се остваривање циљева закона обезбеБује кажњавањем. Свакако да се не залажемо за кршење законом прописаних обавеза и да то кршење треба санкционисати, меБутим и у томе треба да постоји одреБена мера која, сматрамо, није објективно утврБена већ је ригорозна, вероватно под теретом тренутне ситуације.

Законом је требало знатно више дати подстицаја свим правним лицима и предузетницима, полазећи од тога да је далеко већи број њих који послују у складу са законом, добрим пословним обичајима и пословним моралом. 